\title{
Accounting Manipulations and IFRS: Evidence from French Companies
}

\author{
Yosr Nouri ${ }^{1} \&$ Ezzeddine Abaoub ${ }^{2}$ \\ ${ }^{1}$ Higher Business School of Tunis, Tunisia \\ ${ }^{2}$ Faculty of Economics and Management of Tunis, Tunisia \\ Correspondence: Yosr Nouri, Higher Business School of Tunis, 5 rue el Mahdia, app 2, imm 5, 2024 Megrine, \\ Ben Arous, Tunisia. Tel: 2161-8993. E-mail: yosser.noury@yahoo.fr
}

Received: May 19, 2014

doi:10.5539/ijef.v6n11p229

\author{
Accepted: June 16, 2014 \\ Online Published: October 25, 2014 \\ URL: http://dx.doi.org/10.5539/ijef.v6n11p229
}

\begin{abstract}
This paper examines the impact of mandatory adoption of international accounting standards on the income smoothing and earning management. Using a simple of French firms indexed in the CAC all tradable for a period of ten years (2000-2009), we find convincing evidence that the implantation of IFRS contributed to less income smoothing and earning management compared to the local accounting standards, even during the recent economic crisis. Less earning manipulation assures higher levels of reliability information.
\end{abstract}

Keywords: discretionary accruals, earning smoothing, international accounting standards, economic crisis, French, CAC all tradable

\section{Introduction}

In 2002, the European Union has mandated the implementation of International Financial Reporting Standards (IFRS) from January 1st, 2005 for listed companies establishing consolidated accounts. The main purpose is to improve the comparability and the quality of financial reporting in the context of global economy.

In this study, we seek to examine whether the adoption of international accounting standards reduces attempts to manage earning of French companies to achieve better financial information, even during the recent economic crisis.

We focus on France since the transition to international accounting standards, intended primarily to the needs of investors and supporting the dominance of an economic approach to the detriment of historical and fiscal approach, would lead to a new accounting philosophy and an upheaval in financial communication within the French companies that have an accounting system governed by laws and regulations, primarily characterized by a fiscal rigidity designed to meet the needs of lenders and the state (Wehrfritz \& Haller, 2014)

Similarly, previous literature shows that earnings management is higher in code-law countries, with low investor protection rights, such as France, compared to common law countries (Tendeloo \& Vanstraelen, 2005).

Our study includes 145 French companies listed on the stock index CAC ALL TRADABLE. By focusing on a single country, we can better isolate the effect of IFRS on the earning management, since environmental factors remain constant over the period' study.

To test the impact of IFRS on earnings management, we conducted a comparative study where the sample is divided into two equal periods in terms of years, a pre-IFRS period and post-IFRS period, a study covering the whole period and an additional study covering the pre and post recent economic crisis period, after IFRS introduction.

Our empirical results show that the application of IFRS reduces the earning management of French companies, even during the recent economic crisis.

The remainder of this paper is strutured as follows. Section 2 provides theoretical background and hypothesis for the study. In Section 3, we describe our methodology and explain the research design. Our empirical comparative study results are discussed in Section 4. Section 5 presents our robustness tests. Section 6 details our empirical results covering the recent economic crisis period. Section 7 presents our conclusions and future research directions. 


\section{Literature Review and Hypothesis Development}

Compared to the majority of accounting standards, IAS/IFRS are best qualities and their application significantly improves the transparency of information provided by companies and reduces the earnings management (Zeghal, Chtourou \& Fourati, 2012; Iatridis, 2012). Dimitropoulos, Asteriou, Kousenidis and Leventis (2013) showed that the earning management and smoothing declined after the introduction of IFRS in Greece.

Leuz, Nanda and Wysocki (2003) argue that the orientation of IFRS to investors improves the quality of information disseminated since managers are under pressure to provide a true and fair view of the assets and liabilities of the company and engage less in earnings management activities. Barth, Landsman and Lang (2008) argue that reducing the number of accounting options within the IFRS limits the earnings management practised by managers. The accounting standards retain two treatments for the same problem: benchmark treatment and allowed alternative treatment. As the IASB framework requires disclosure of more information and requires companies to publish financial statements on annual and semi-annual basis, as well as quarterly reporting (example: IAS 34: Interim Financial Reporting), Daske (2006) found that communication of a higher volume of information than required by the majority of national accounting systems led to advanced transparency in accounting values, which limits the earnings management. Similarly, Fu, Kraft and Zhang (2012) point out that the firms adopting IFRS are expected to provide more disclosure, which increases transparency and reduces the level of accruals. According to Landsman, Mayd and Jacob (2012) and Barth, Konchitchki \& Landsman (2013) increased disclosure required by IFRS leads to greater transparency of accounts and a diminution of information asymmetry which reduces the opportunistic earnings management. Studies show that reducing the discretionary latitude of managers comes essentially from the principle of primacy of economic reality on the legal, illustrated by standard IAS 17 'Leases', which requires the recognition of the leased item in the lessee assets under contracts of lease-financing instead of registering it in off-balance sheet, and the principle of fair value (Note 1). Cairns, Massoudi, Taplin and Tarca (2011) argue that fair value can reflect the economic reality compared to historical cost, reducing opportunistic earnings management. Casta (2000) stated that "in terms of comparability of financial statements, presenting equivalent valuations for the same financial instrument, regardless of its date of acquisition, fair value makes practices of opportunistic earnings management quite pointless. In addition, the fair value would ensure neutrality of information produced by companies and would restore measuring performance more exhaustiveness." According to Plantin, Sapra and Shin (2008a), the valuation at fair value of transactions bring managers to adopt a less opportunistic management behaviour compared to applying the historical cost because accounting of instruments is purely exogenous and is not under the control of the direction. However, several researchers have shown that IFRS standard does not reduce the earnings management. Cormier and Martinez (2006) find that the adoption of international accounting standards in the French context increases the room for manoeuvre to managers with regard to earning smoothing in order to reduce the gap between announced forecasts and actual earnings, in case of an IPO. Defond (2010) finds that the transition to a principles-based accounting should give more flexibility to companies and thus enable them to benefit more from the earnings management. On fair value, according to researchs, the main drawback of this value is the unjustified increase volatility (Note 2) in results due to the fact that this method does not take consideration the accounting principle of prudence, it treats latent profits and latent losses in the same way, which can lead to high instability in performance and a massive practise of the earnings management to reduce this variability (Ghosh \& Olsen, 2008). In contrast, other empirical studies have shown that, earnings management and earnings volatility caused by the application of fair value, under IFRS show a negative relationship (Iatridis, 2012).

By the recent financial crisis (2007-2009), the fair value was severely criticized (The procyclic character of the fair value and the difficulty of its assessment under an illiquid market) and the role played by the IFRS has been widely debated, especially for financial institutions. Magnan (2009) concluded that the fair value amplified crisis especially for institutions that held assets during the crisis in markets that have experienced the lack of liquidity. The recent economic crisis is due to a financial crisis loans "subprimes" in the US in 2007. This crisis was transformed into a banking, stock market and economic crises not only in the United States but in Europe in 2008. From end 2007 to end 2008, the stock market prices of listed companies indexed in the CAC ALL TRADABLE have devalued by $13 \%$ to over $50 \%$. The volatility of stock market prices is exceptional in the petroleum, trade and industrial sector. The conditions of access to bank loans are more difficult for companies and the fluctuations of currencies are significant. These situations determined by economic crises can motivated managers to manage earning (Gorgan, Gorgan, Dumitru \& Pitulice, 2012).

In line with the works cited above, we argue that the earning management of French companies would be lower under IFRS standards compared to French standards, even during the recent economic crisis. 
In our study, we test the following hypothesis:

The adoption of international accounting standards by French companies reduces earnings management, even during the recent economic crisis.

\section{Research Design}

\subsection{Sample and Data}

The sample consists of index CAC ALL TRADABLE composed of French listed companies. These companies are observed over a period of 10 years from 2000 to 2009. This population consisted of 2500 observations; we excluded companies operating in the financial sector (380). These companies are governed by specific regulations and by financial characteristics different from those governing non-financial companies. The accounting data regarding companies were developed according to the French local standards for the period between 2000 and 2004, and according to international Financial Reporting Standards for the period between 2005 and 2009. Our sample does not include "early time adopters" of IFRS. All companies in the sample have adopted international accounting standards in 2005. To perform our analysis, and to compare the results between the pre and post IFRS periods, we have elected a constant sample over the entire period of study, which would mean excluding companies that have been introduced in the CAC ALL TRADABLE INDEX after 2000 and those that were removed before 2009 (150). We have also eliminated companies whose financial data were not available during the period of our study (300). We also excluded companies which financial year not ending by December 31 (220).

Our final sample consists of 1450 observations-firms-years.

Table 1 and Table 2 below describe the sample selection process and the sample industries distribution, respectively.

Table 1. Sample selection process

\begin{tabular}{lc}
\hline Initial number of observations & 2500 \\
\hline Companies with financial nature & $(380)$ \\
Companies introduced after 2000 and removed before 2009 & $(150)$ \\
Missing data in Worldscope and Datastream & $(300)$ \\
Companies whose financial year not ending by $31 / 12$ & $(220)$ \\
Total of Sample & 1450 \\
\hline
\end{tabular}

The data relating to Companies in our sample is collected from Worldscope and Datastream database (Thomson Reuters) 2010 and annual reports of each company.

Table 2. Industries distribution

\begin{tabular}{lcc}
\hline industries & Number of observations by industry & $\%$ of the sample \\
\hline Industry & 522 & $36 \%$ \\
Trade and Consumer Goods & 290 & $20 \%$ \\
Health care & 130 & $9 \%$ \\
Services & 203 & $14 \%$ \\
Real estate and buildings & 145 & $10 \%$ \\
Technology & 160 & $11 \%$ \\
Total & 1450 & $100 \%$ \\
\hline
\end{tabular}

\subsection{Earnings Management}

We use three proxies of earnings management that are commonly used in the accounting literature, two proxies are related to earning smoothing and the other refers to discretionary accruals (DA).

\subsubsection{Earnings Smoothing}

The first measure concerns the standard deviation of the change in net income $(\Delta \mathrm{NI})$. Given that the change in net income can be attributed to factors other than the financial information system, we use the standard deviation of the change in net income $\left(\Delta \mathrm{NI}^{*}\right)$ residuals (Lang, Raedy, \& Wilson 2006; Barth et al., 2008) from the 
following regression model (1):

$$
\Delta N I_{i t}=\partial_{0}+\partial_{1} O C F_{i t}+\partial_{2} L E V_{i t}+\partial_{3} R O E_{i t}+\partial_{4} R O A_{i t}+\partial_{5} S I Z E_{i t} \partial_{6} A U G C_{i t}+\partial_{7} G R O W T H_{i t}+\varepsilon_{i t}
$$

Where, $\triangle \mathrm{NI}$ is the annual change in net income scaled by lagged total assets, OCF is Operating cash flow to lagged total assets, LEV is the level of debt (total debt/owners' equity), ROE is the net income to equity, ROA is the net income to total assets, SIZE is the natural logarithm of the market capitalization of the firm $\mathrm{i}$ during the year t, AUGC is a binary variable that takes 1 when the firm has carried out a capital increase of more than $10 \%$ of the total shares outstanding during the year, 0 otherwise, GROWTH is the percentage of annual variation in sales.

The variable description and measurement are summarized in Table 4.

If managers take no discretionary action to smooth earnings, then they should be relatively volatile and fluctuate over time. Therefore, we interpret a smaller variance of the change in net income as suggestive of earnings smoothing.

The second measure of earnings smoothing concerns the ratio of standard deviation of the change in net income $\left(\Delta \mathrm{NI}^{*}\right)$ to the standard deviation of the change in cash flows $\left(\Delta \mathrm{CF}^{*}\right)$. Following Barth et al. (2008) and Ahmed, Neel and Wang (2013), we use the ratio of the standard deviation of the change in net income $\left(\Delta \mathrm{NI}^{*}\right)$ to the standard deviation of the change in cash flows $\left(\Delta \mathrm{CF}^{*}\right)$ residuals, from the two regression models (2):

$$
\begin{gathered}
\Delta N I_{i t}=\partial_{0}+\partial_{1} O C F_{i t}+\partial_{2} L E V_{i t}+\partial_{3} R O E_{i t}+\partial_{4} R O A_{i t}+\partial_{5} S I Z E_{i t}+\partial_{6} A U G C_{i t}+\partial_{7} G R O W T H_{i t}+\varepsilon_{i t} \\
\Delta C F_{i t}=\partial_{0}+\partial_{1} O C F_{i t}+\partial_{2} L E V_{i t}+\partial_{3} R O E_{i t}+\partial_{4} R O A_{i t}+\partial_{5} S I Z E_{i t}+\partial_{6} A U G C_{i t}+\partial_{7} G R O W T H_{i t}+\varepsilon_{i t}
\end{gathered}
$$

Where, $\triangle \mathrm{CF}$ is the annual change of operating cash flow scaled by lagged total assets.

The variable description and measurement are summarized in Table 4.

Ahmed et al. (2013) declare that if managers use accruals to smooth the changes in cash flows when reporting income, the variance of the change in net income should be less than the variance of the change in cash flows. So, we interpret a smaller value of this ratio as suggestive of earnings smoothing and manipulation. (Cai, Rahman, \& Courtenay, 2014; Lin, Riccardi, \& Wang, 2012).

\subsubsection{Discretionary Accruals (DA)}

Discretionary accruals, as the proxy for earning management, are used in a variety of studies. (Theo, Welch, \& Wong, 1998; Zeghal et al., 2011). Various models have been adopted to measure discretionary accruals (Dechow, Sloan, \& Sweeney, 1995; Jones, 1991; Kothari, Leone, \& Wasley, 2005). Following the previous studies, in the present we adopted the cross-sectional Jones (1991) model, as modified by Kothari et al. (2005), in order to estimate the discretionary accruals following a performance matching approach.(Dimitropoulos et al., 2013).

The Kothari et al. (2005) model (3) estimates discretionary accruals as a function of changes in sales, the levels of property, plant and equipment, and the level of return on assets:

$$
T A_{i t} / A_{i t-1}=\beta_{0}+\beta_{1}\left(1 / A_{i t-1}\right)+\beta_{2}\left(\Delta(R E V-A R)_{i t} / A_{i t-1}\right)+\beta_{3}\left(P P E_{i t} / A_{i t-1}\right)+\beta_{4} R O A_{i t}+\varepsilon_{i t}
$$

Where, TAit is the total accruals for company $\mathrm{i}$ in year $\mathrm{t}$, computed as the difference between net income before extraordinary items and cash flow from operations; REVit is the change in revenues for company $i$ between year $\mathrm{t}$ and $\mathrm{t}-1$; ARit is the change in accounts receivable for company $\mathrm{i}$ between year $\mathrm{t}$ and $\mathrm{t}-1$; PPEit is the gross property, plant, and equipment for company $\mathrm{i}$ in year $\mathrm{t}$; ROAit is the return on assets for company $\mathrm{i}$ in year $\mathrm{t}$. All variables are deflated by lagged total assets to control of heteroscedasticity.

Kothari et al. (2005) argue that the inclusion of a constant term in the Jones (1991) model provides an additional control for heteroscedasticity not alleviated by deflating the variables with total assets. A constant term also mitigates problems arising from omitted size Variables (Brown, Lo, \& Lys, 1999) and the inclusion of a profitability measure (ROA) is designed to enhance the effectiveness of the performance matching methodology.

Non-Discretionary Accruals (NDA) are residuals obtained from the estimation of this model. Using the estimated coefficients $\left(\partial_{1}, \partial_{2}, \partial_{3}, \partial_{4}\right)$, we evaluate the nondiscretionary accruals (NDA) for each company in our sample:

$$
N D A_{i t} / A_{i t-1}=\partial_{1}\left(1 / A_{i t-1}\right)+\partial_{2}\left(\Delta(R E V-A R)_{i t} / A_{i t-1)}+\partial_{3}\left(P P E_{i t} / A_{i t-1}\right)+\partial_{4} R O A_{i t}\right.
$$

The discretionary accruals are obtained by calculating the difference between total accruals and estimated non-discretionary accruals:

$$
D A_{i t}=T A_{i t}-N D A_{i t}
$$


A larger value of discretionary accruals represents higher earnings management (Cai et al., 2014; Zéghal et al., 2011).

We conduct a comparative study between pre -IFRS and post- IFRS period. In the following test, we will examine the differences between the discretionary accruals means calculated for the periods before and after the adoption of IFRS. For our sample, we examine the directional values of discretionary accruals (PDA / NDA) and their absolute value |DA|. (Houque, Van Zijl, Dunstan, \& Karim, 2012; Zéghal et al., 2011; Landsman et al., 2012). The absolute value of discretionary accruals is presented in the previous literature as a measure of the extent of managerial discretion. The resort to the absolute value captures the reversionary discretionary accruals effect. The earnings management' direction, whether upward or downward, allows better understanding of the evolution of discretionary accruals according to motivations to which it obeys (Marra, Mazzola, \& Prencipe, 2011).

The comparison result is shown in Table 3.

Before beginning this comparison, we checked the normality of variables. We used for this purpose Skewness and Kurtosis tests. The results of these tests showed that variables do not follow the normal distribution. Accordingly, and given that it is a comparison of means for the same sample observed over two periods, the appropriate test is WILCOXON (Zéghal et al., 2011).

Table 3. Earnings management: test of difference between two period: pre-IFRS period (00-04) and post-IFRS period (05-09)

\begin{tabular}{ccccc}
\hline Variables & $\mathbf{N}$ & $\begin{array}{c}\text { Pre-IFRS group (00-04) } \\
\text { mean }\end{array}$ & $\begin{array}{c}\text { Post-IFRS group (05-09) } \\
\text { mean }\end{array}$ & $\begin{array}{c}\text { Wilcoxon } \\
\text { test }\end{array}$ \\
\hline DA $\mid$ & 1450 & 0.0521 & 0.0290 & $-3.627^{* * *}$ \\
& & & & $(0.000)$ \\
DA & 1450 & 0.0147 & 0.0121 & $-5.024^{* * *}$ \\
& & & & $(0.000)$ \\
DA $\geq 0$ & 870 & 0.0412 & 0.0335 & $-4.378^{* * *}$ \\
& & & & $(0.000)$ \\
DA $<0$ & 580 & -0.0265 & -0.0213 & -0.251 \\
& & & & $(0.186)$ \\
\hline
\end{tabular}

Note. $|\mathrm{DA}|$ : the absolute value of discretionary accruals. DA: the discretionary accruals. $\mathrm{DA} \geq 0$ : the positive discretionary accruals. DA $<0$ : the negative discretionary accruals. $* * *$ denotes significant level at $1 \%$.

Table 3 shows that the means of the different variables are significantly lower in the post IFRS period except for the variable $\mathrm{DA}<0$ which is not significant. This suggests that the adoption of IFRS reduce earning management level.

These outcomes may lead us to retain as part of our analysis the absolute and positive value of discretionary accruals as the dependent variables in the following models (6-7) (Iatridis, 2010-2012):

$$
\begin{aligned}
& \left|D A_{i t}\right|=\beta_{0}+\beta_{1} O C F_{i t}+\beta_{2} L E V_{i t}+\beta_{3} R O E_{i t}+\beta_{4} R O A_{i t}+\beta_{5} S I Z E_{i t}+\beta_{6} A U G C_{i t}+\beta_{7} G R O W T H_{i t}+\varepsilon_{i t} \\
& P A D_{i t}=\beta_{0}+\beta_{1} O C F_{i t}+\beta_{2} L E V_{i t}+\beta_{3} R O E_{i t}+\beta_{4} R O A_{i t}+\beta_{5} S I Z E_{i t}+\beta_{6} A U G C_{i t}+\beta_{7} G R O W T H_{i t}+\varepsilon_{i t}
\end{aligned}
$$

Where $|\mathrm{DA}|$ is the absolute value of performance-matched discretionary accruals from the cross-sectional Jones (1991) model as being modified by Kothari et al. (2005), PAD is the positive value of performance-matched discretionary accruals.

The variable description and measurement are summarized in Table 4.

Given the nature of this study and data, we used a statistical model of panel data, studied over two periods (before and after the adoption of IFRS) (Stock \& Watson, 2003).

We expect that the introduction of IFRS will limit the earnings management. We conduct for this purpose, a comparative study between the pre- IFRS period (2000-2004) and post-IFRS period (2005-2009). Regarding earnings management by discretionary accruals, we expect lower coefficients in the post IFRS period. Concerning earning smoothing, we expect that French firms have higher values of the $\operatorname{SD}\left(\Delta \mathrm{NI}^{*}\right)$ and the ratio $\mathrm{SD}\left(\Delta \mathrm{NI}^{*}\right) / \mathrm{SD}\left(\Delta \mathrm{CF}^{*}\right)$ during the IFRS adoption period. 
The trend analysis of discretionary accruals over time is summarized in the above figures.

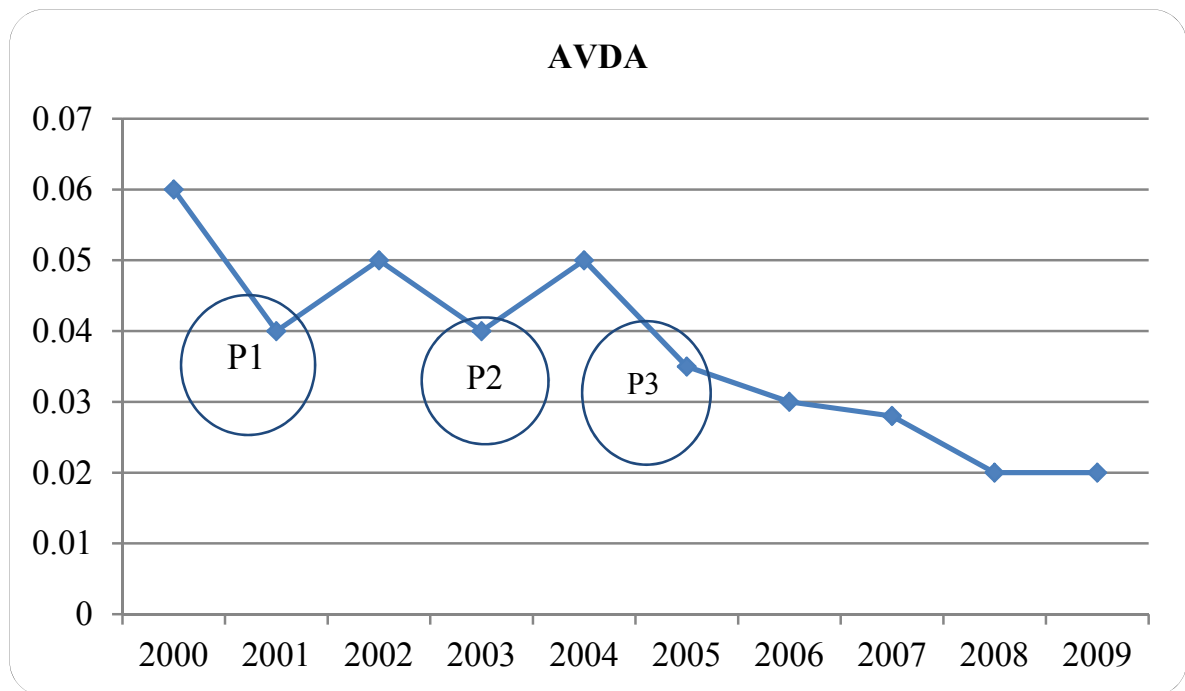

Figure 1. Evolution of the absolute value average of discretionary accruals

Note. AVDA $\mathrm{t}_{\mathrm{t}}$ : Average of absolute value of discretionary accruals for the year $\mathrm{t}$.

P1: 2000-2001: period of financial scandals,

P2: 2003: approval of the Financial Security Law in France,

P3: 2005: adoption of international accounting standards.

From Figure 1, the magnitude of discretionary accruals is high in the years preceding the transition to IFRS in 2005. Starting from 2005 the year of the adoption of IFRS, the values fall. This decline continues on post- IFRS years to reach $2 \%$ in 2009 .

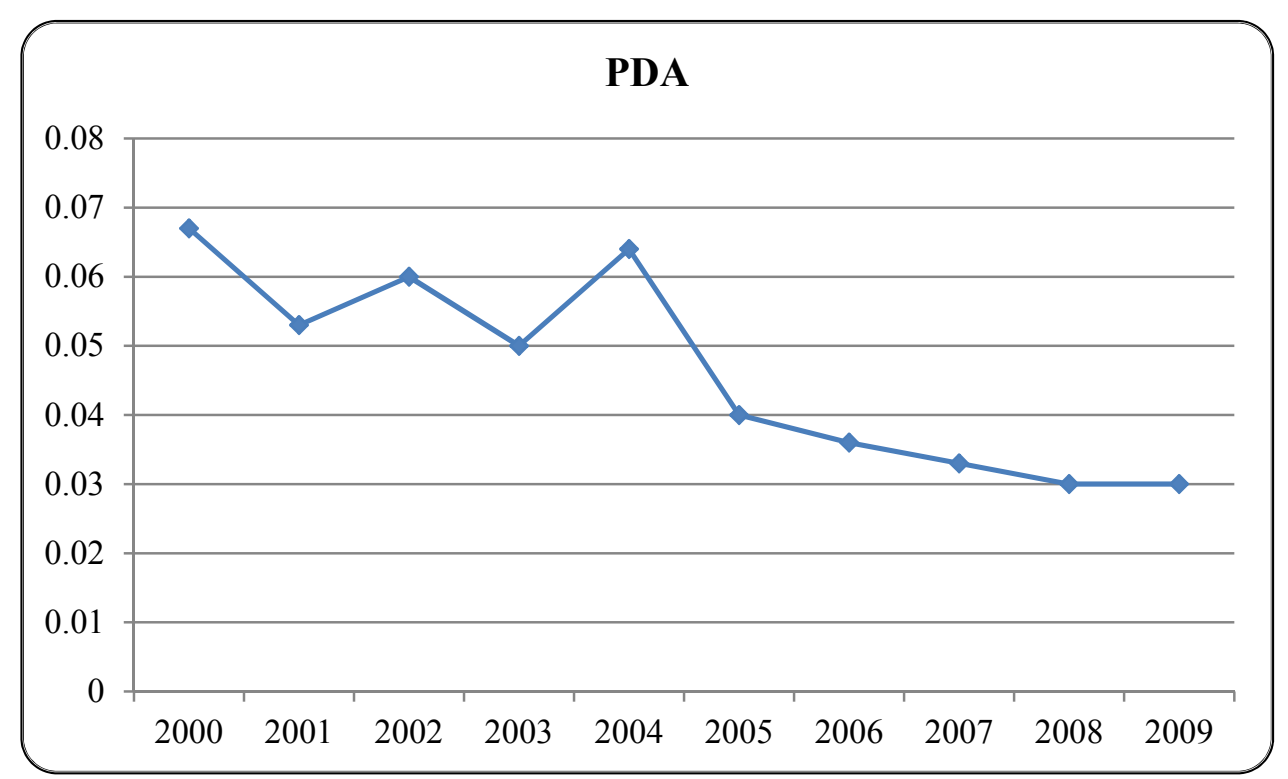

Figure 2. Evolution of the positive discretionary accruals average

Note. $\mathrm{PDA}_{\mathrm{t}}$ : average of the positive discretionary accruals for the year $\mathrm{t}$.

Similarly, average of positive discretionary accruals shown in Figure 2 is high on pre- IFRS period and tends to fall on post- IFRS period. 


\subsection{Variables Description and Measurement}

To analyze the impact of IFRS on earnings management, we will incorporate variables that are selected through previous literature review and which have an impact on the earning management. We control the size of the firm "SIZE" as the literature review shows that the size of the company affects the level of earnings management. According to political costs hypothesis by Watts and Zimmerman (1978-1986), big size firms resort more to earnings management downward in order to minimize political costs. Lobo and Zhou (2001) do not expect in their model the impact of firm size on earnings management because they consider the effect of this variable not clear. Big size companies have more efficient systems of internal control, which provide more reliable information and make them further monitored by financial market and analysts; this reduces information asymmetry problems and makes earnings management difficult to achieve compared to small companies. The size of the firm is measured on this research by the logarithm of the market capitalization of the firm. (Perry \& Williams, 1994). We control the debt level which can affect the earnings management level. The companies heavily indebted have stronger reasons to manage upward their accounting earnings to not to violate covenants of debt contracts (Watts \& Zimmerman, 1978-1986; Xiong, 2006). They can manage the earning down to force negotiations in case of financial difficulties. In this study, we expect that leverage will have a positive impact on earning management. We use total debt ratio / total asset as a measure of the debt level (Dechow et al., 1995). We include "OCF", "ROA" and "ROE" as variables measuring the company performance, since previous studies show that the poor performance is a motivation for upward earnings management (Lobo \& Zhou, 2001). We expect a significant and negative effect of these variables on the earning management level. We control the increase of capital for companies in our sample because operations on shares capital lead to upward earning management. (Thong, Ding, \& Lim, 2008). Teo, Welch \& Wong (1998) show that managers use earning management for the period prior to an increase capital operation. They note that the published results are very high at the time of the transaction and drop significantly after this period. Like Lobo and Zhou (2001), the variable AUGC is a binary variable that takes 1 when the firm has carried out a capital increase of more than $10 \%$ of the total shares outstanding during the year, 0 otherwise. We expect a positive impact of this variable on earning management. We have introduced the percentage of annual variations in sales, since this percentage affects the level of earnings management (Dimitropoulos et al., 2013).

The variable description and measurement are summarized in Table 4.

Table 4. Variable description and measurement

\begin{tabular}{|c|c|c|}
\hline Variables & Description & Measurement \\
\hline $\mathrm{OCF}$ & Operating cash flow & Operating cash flow to lagged total assets \\
\hline LEV & Leverage ratio & Total debt to total assets \\
\hline ROE & Return on equity & net income to equity \\
\hline ROA & Return on Assets & Net income to total assets \\
\hline Size & Log market capitalization of the company & $\begin{array}{l}\text { Stock price at end of period multiplied by the } \\
\text { number of shares outstanding for the same period }\end{array}$ \\
\hline AUGC & Capital increase & $\begin{array}{l}\text { Binary variable that takes } 1 \text { when the firm has } \\
\text { carried out a capital increase of more than } 10 \% \text { of } \\
\text { the total shares outstanding during the year, } 0 \\
\text { otherwise }\end{array}$ \\
\hline Growth & Sales growth & Annual percentage change in sales \\
\hline
\end{tabular}

\section{Empirical Comparative Study Results and Discussion}

\subsection{Descriptive Statistics}

Table 5 below shows descriptive statistics of variables during pre-IFRS (2000-2004) period and post-IFRS (2005-2009) period.

We will study the significance of differences between variables used in this research and calculated for the periods before and after the adoption of IFRS. Prior to this comparison, we checked the normality of variables. We used for this purpose Skewness and Kurtosis tests. The results of these tests show that some variables follow the normal distribution and others not. Accordingly, we use the t-test comparison for variable following normal distribution and the non parametric Wilcoxon test comparison for the other variables and the independence test of Chi-2 for discrete variable capital increase (AUGK). 
On average, firms in our sample exhibit a greater change in earnings and more negative change in cash-flows in the post-adoption period compared to the pre-adoption period. Companies in our sample also have, on average, lower cash-flows in the period post-IFRS compared to the pre-IFRS period $(0.084<0.125)$ and significantly higher performance $(1 \%)$ in the post-IFRS period $(0.074>-0.083 ; 0.146>-0.072)$. In the pre-IFRS period, companies tend to have more debts. The size of the company, capital increases and the rate of sales growth are on average higher in the post-IFRS period.

Table 5. Descriptive statistics relating to variables used in analyses

\begin{tabular}{|c|c|c|c|c|c|c|c|c|c|}
\hline \multirow[b]{2}{*}{ variables } & \multicolumn{3}{|c|}{$\begin{array}{c}\text { Pre-IFRS (2000-2004) } \\
\quad \mathrm{N}=725\end{array}$} & \multicolumn{3}{|c|}{$\begin{array}{c}\text { Post-IFRS(2005-2009) } \\
\mathrm{N}=725\end{array}$} & \multirow[b]{2}{*}{ T-test } & \multirow[b]{2}{*}{ Wilcoxon test } & \multirow[b]{2}{*}{$\mathrm{X}^{2}$ test } \\
\hline & Mean & Median & Std. Dev & Mean & Median & Std. Dev & & & \\
\hline$\Delta \mathrm{NI}$ & -0.063 & -0.049 & 0.162 & 0.097 & 0.059 & 0.184 & $\mathrm{n} / \mathrm{a}$ & $2.556^{* * *}(0.000)$ & $\mathrm{n} / \mathrm{a}$ \\
\hline$\Delta \mathrm{CF}$ & -0.014 & -0.035 & 0.146 & -0.016 & -0.042 & 0.153 & $\mathrm{n} / \mathrm{a}$ & $-5.644 * * *(0.000)$ & $\mathrm{n} / \mathrm{a}$ \\
\hline OCF & 0.125 & 0.101 & 0.275 & 0.090 & 0.084 & 0.226 & $\mathrm{n} / \mathrm{a}$ & $-3.399 * *(0,028)$ & $\mathrm{n} / \mathrm{a}$ \\
\hline LEV & 1.330 & 1.289 & 1.020 & 1.144 & 1.065 & 1.036 & $\begin{array}{c}-0.186^{*} \\
(0,053)\end{array}$ & $\mathrm{n} / \mathrm{a}$ & $\mathrm{n} / \mathrm{a}$ \\
\hline ROE & -0.083 & 0.053 & 0.890 & 0.074 & 0.043 & 0.651 & $\mathrm{n} / \mathrm{a}$ & $3.024 * * *(0.000)$ & $\mathrm{n} / \mathrm{a}$ \\
\hline ROA & -0.072 & 0.042 & 0.125 & 0.146 & 0.130 & 0.198 & $\mathrm{n} / \mathrm{a}$ & $3.357^{* * *}(0.000)$ & $\mathrm{n} / \mathrm{a}$ \\
\hline SIZE & 3.927 & 3.763 & 1.677 & 4.100 & 3.038 & 1.880 & $\begin{array}{r}0.173^{* *} \\
(0,029)\end{array}$ & $\mathrm{n} / \mathrm{a}$ & $\mathrm{n} / \mathrm{a}$ \\
\hline AUGC & 0.108 & $\mathrm{n} / \mathrm{a}$ & $\mathrm{n} / \mathrm{a}$ & 0.200 & $\mathrm{n} / \mathrm{a}$ & $\mathrm{n} / \mathrm{a}$ & $\mathrm{n} / \mathrm{a}$ & $\mathrm{n} / \mathrm{a}$ & $\begin{array}{c}0.092^{* *} \\
(0.012)\end{array}$ \\
\hline GRWOTH & 0.045 & 0.026 & 0.222 & 0.058 & 0.030 & 0.433 & $\begin{array}{l}0.014^{*} \\
(0,062)\end{array}$ & $\mathrm{n} / \mathrm{a}$ & $\mathrm{n} / \mathrm{a}$ \\
\hline
\end{tabular}

Note. $\Delta \mathrm{NI}$ is annual change in net income scaled by lagged total assets, $\triangle \mathrm{CF}$ is annual change in the operating cash flow scaled by lagged total assets, OCF is operating cash flow to lagged total assets, LEV is the leverage ratio estimated as total debt to total assets, ROE is return on equity estimated as net income to owners' equity, ROA is return on Assets estimated as net income to total assets, SIZE is the natural logarithm of market capitalization, AUGC is a binary variable that takes 1 when the firm has carried out a capital increase of more than $10 \%$ of the total shares outstanding during the year, 0 otherwise, GROWTH is the annual percentage change in sales. ***denotes significant level at $1 \%$;* denotes significant level at $5 \%$; *denotes significant level at $10 \%$.

\subsection{Regression Results}

To test the impact of international accounting standards on the earning management, we use two proxies: earning smoothing and discretionary accruals.

Table 6. Univariate evidence on earnings smoothing

\begin{tabular}{lccc}
\hline & Pre-IFRS $(00-04)$ & Post-IFRS $(05-09)$ & Wilcoxon-test \\
& $\mathrm{N}=725$ & $\mathrm{~N}=725$ & \\
\hline $\mathrm{SD}(\Delta \mathrm{NI} *) / \mathrm{SD}\left(\Delta \mathrm{CF}^{*}\right)$ & 0.01692 & 0.02684 & $2.025^{* * *}$ \\
$\mathrm{SD}(\Delta \mathrm{NI})$ & 0.2261 & 0.3054 & $3.238^{* * *}$ \\
\hline
\end{tabular}

Note. $\Delta \mathrm{NI}^{*}$ and $\triangle \mathrm{CF} *$ are the residuals from the annual regressions of the following models respectively:

$\Delta \mathrm{NI}_{\mathrm{it}}=\partial_{0}+\partial_{1} \mathrm{OCF}_{\mathrm{it}} \partial_{2} \mathrm{LEV}_{\mathrm{it}}+\partial_{3} \mathrm{ROE}_{\mathrm{it}}+\partial_{4} \mathrm{R} \mathrm{O} \mathrm{A}_{\mathrm{it}}+\partial_{5} \mathrm{SIZE}_{\mathrm{it}} \partial_{6} \mathrm{AUGC}_{\mathrm{it}}+\partial_{7} \mathrm{GROWTH}_{\mathrm{it}}+\varepsilon_{\mathrm{it}}$.

$\Delta \mathrm{CF}_{\mathrm{it}}=\partial_{0}+\partial_{1} \mathrm{OCF}_{\mathrm{it}}+\partial_{2} \mathrm{LEV} \mathrm{V}_{\mathrm{it}}+\partial_{3} \mathrm{ROE}_{\mathrm{it}}+\partial_{4} \mathrm{R} \mathrm{O} \mathrm{A}_{\mathrm{it}}+\partial_{5} \mathrm{SIZE}_{\mathrm{it}}+\partial_{6} \mathrm{AUGC}_{\mathrm{it}}+\partial_{7} \mathrm{GROWTH}_{\mathrm{it}}+\varepsilon_{\mathrm{it}}$.

$\triangle \mathrm{NI}$ : annual change in net income scaled by lagged total assets, $\triangle \mathrm{CF}$ : annual change in the operating cash flow scaled by lagged total assets.

*** denotes significant level at $1 \%$.

Table 6 below indicates the results on earning smoothing and shows that standard deviation of the change in net income $\left(\mathrm{SD}\left(\Delta \mathrm{NI}^{*}\right)\right)$ is significantly higher in the post-IFRS period. Similarly, the ratio of the standard deviation 
of the change in net income $\left(\Delta \mathrm{NI}^{*}\right)$ to the standard deviation of the change in cash flows $\left(\Delta \mathrm{CF} \mathrm{F}^{*}\right)$ $\left(\mathrm{SD}\left(\Delta \mathrm{NI}^{*}\right) / \mathrm{SD}\left(\Delta \mathrm{CF}^{*}\right)\right)$ is significantly higher in the post-IFRS period. This difference was estimated using the Wilcoxon test. This finding demonstrates that with the implementation of IFRS, French companies resort less to smoothing earnings in spite of the volatile of the fair value introduced by IFRS and criticized by several researchers. (Ghosh \& Olsen, 2008).

This result is consistent with previous studies (Barth et al., 2008; Chen, Tang, Jiang, \& Lin, 2010; Dimitropoulos et al., 2013) showing that the adoption of IFRS reduces earnings management.

Table 7 and Table 8 below show the results for the estimation of model (6) and (7) respectively, that include the absolute value of performance-matched discretionary accruals $|\mathrm{DA}|$ et the positive value of performance-matched discretionary accruals PDA as dependent variables, respectively.

To apply the regression models, we need to verify the absence of multicollinearity between variables. The correlation matrix allows us to identify the potential problem of multicollinearity between variables. Correlation matrices in this study have higher coefficients $(\rho>0.8)$, this may indicate a problem of multicollinearity between variables. We will calculate the Variance Inflation Factor (VIF) which detects multicollinearity between variables. A serious multicollinearity problem exists between variables of a model when VIF values exceed 10. By applying this test to values of our models, in general we obtained VIF factors that do not exceed 3.It means that the model does not contain multicollinearity

From Table 7 below, we can conclude that the model (6) tested is generally significant, $\mathrm{R}^{2}$ has a value of $20 \%$ in the pre-IFRS period and $38 \%$ in the post-IFRS period, which are in line with prior studies. (Dimitropoulos et al., 2013; Marra et al., 2011). We reject the null hypothesis stating that all coefficients are zero $(\mathrm{P}<5 \%)$. The $\mathrm{X}^{2}$ test shows a probability less than 5\%, allowing us to retain the fixed-effects estimator.

Table 7 shows that "OCF", "ROE" and "ROA" are significantly and negatively related to the variable $|\mathrm{DA}|$, for pre and post IFRS periods, at the $1 \%$ level. The signs of these variables that represent the performance of the company are consistent with our expectations and the literature which states that weak performance leads to earnings management. (Barth et al., 2008; Iatridis, 2012; Zéghal et al., 2012). However, the coefficients of these variables are lower in the post IFRS period. This indicates that with the application of IFRS, companies with low performance resort less to the management of accruals. The coefficient of debt "LEV" is significantly positive in the pre- and post-IFRS period. In the post-IFRS period, this coefficient is lower and less significant, indicating that debt is an important motivation for earnings management in the pre-IFRS period. The "SIZE" variable is negatively and significantly related to the variable $|\mathrm{DA}|$ for pre- and post-IFRS periods. The coefficient is higher and less significant in the post IFRS period. This result is explained by the fact that big companies applying IFRS are monitored by financial analysts and other stakeholders, which play the role of external controllers which limits earnings management. (Bozec, 2008). The coefficients of variables AUGC and GROWTH are positive and significant in the pre and post IFRS periods. However, they are higher and more significant in the pre-IFRS period, indicating that the operations of capital increase and sales growth are genuine motivation for earnings management in this period. (Thong et al., 2008).

Overall, the empirical results indicate that the adoption of IFRS has decreased the magnitude of discretionary accruals.

Table 7. Regression results on Discretionary Accruals with $|\mathrm{DA}|$

\begin{tabular}{|c|c|c|c|}
\hline Variables & $\begin{array}{c}\text { Pre-IFRS(00-04) } \\
\text { (p-value })\end{array}$ & $\begin{array}{c}\text { Post-IFRS(05-09) } \\
\text { (p-value })\end{array}$ & Expected sign \\
\hline Constant & $\begin{array}{c}0.144 * * * \\
(0.000)\end{array}$ & $\begin{array}{c}0.008^{* * *} \\
(0.000)\end{array}$ & \\
\hline $\mathrm{OCF}$ & $\begin{array}{c}-0.052 * * * \\
(0.007)\end{array}$ & $\begin{array}{c}-0.024 * * * \\
(0.005)\end{array}$ & - \\
\hline LEV & $\begin{array}{r}0.082 * * \\
(0.023)\end{array}$ & $\begin{array}{l}0.045^{*} \\
(0.098)\end{array}$ & + \\
\hline ROE & $\begin{array}{c}-0.020 * * * \\
(0.000)\end{array}$ & $\begin{array}{c}-0.010 * * * \\
(0.000)\end{array}$ & - \\
\hline ROA & $\begin{array}{c}-0.030 * * * \\
(0.000)\end{array}$ & $\begin{array}{c}-0.015 * * * \\
(0.000)\end{array}$ & - \\
\hline SIZE & $\begin{array}{c}-0.042 * * \\
(0.042)\end{array}$ & $\begin{array}{l}-0.094 * \\
(0.098)\end{array}$ & $+/-$ \\
\hline
\end{tabular}




\begin{tabular}{lccc}
\hline AUGC & $0.066^{* * *}$ & $0.039^{* *}$ & + \\
& $(0.003)$ & $(0.028)$ & + \\
GROWTH & $0.053^{* *}$ & $0.024^{*}$ & \\
& $(0.019)$ & $(0.075)$ & \\
Adjusted R-square & 0.20 & 0.38 & \\
F-stat & $10.492^{* *}$ & $13.091^{* *}$ & 725 \\
$\mathrm{~N}$ & 725 & 725 \\
\hline
\end{tabular}

Note. $* * *$ denotes significant level at $1 \%$;* denotes significant level at $5 \%$; denotes significant level at $10 \%$. We report p-values in parentheses below the coefficients.

$$
\left|\mathrm{DA}_{\text {it }}\right|=\beta_{0}+\beta_{1} \mathrm{OCF}_{\text {it }}+\beta_{2} \mathrm{LEV}_{\text {it }}+\beta_{3} \mathrm{ROE}_{\text {it }}+\beta_{4} \mathrm{ROA}_{\text {it }}+\beta_{5} \mathrm{SIZE}_{\text {it }}+\beta_{6} \mathrm{AUGC}_{\text {it }}+\beta_{7} \mathrm{GROWTH}_{\text {it }}+\varepsilon_{\text {it }} .
$$

The dependent variable is the absolute value of discretionary accruals. OCF is operating cash flow to lagged total assets, LEV is the leverage ratio estimated as total debt to total assets, ROE is return on equity estimated as net income to owners' equity, ROA is return on Assets estimated as net income to total assets, SIZE is the natural logarithm of market capitalization, AUGC is a binary variable that takes 1 when the firm has carried out a capital increase of more than $10 \%$ of the total shares outstanding during the year, 0 otherwise, GROWTH is the annual percentage change in sales. The model has been estimated including year fixed effects.

From Table 8 below, we can conclude that the model 7 tested is generally significant, $\mathrm{R}^{2}$ has a value of $17 \%$ in the pre-IFRS period and $25 \%$ in the post-IFRS period, which are in line with prior studies. (Iatridis, 2012; Zéghal et al., 2012). We reject the null hypothesis stating that all coefficients are zero. The $\mathrm{X}^{2}$ test shows a probability less than $5 \%$, allowing us to retain the fixed-effects estimator. Table 8 confirms the results of the previous table, except for the coefficient of debt ratios "LEV" and "SIZE" which have lost their significances. The debt ratio and the firm size are no longer a motivation for earnings management upward for companies applying IFRS. French companies employ less positive discretionary accruals after the introduction of IFRS.

Table 8. Regression results on discretionary accruals with PDA

\begin{tabular}{|c|c|c|c|}
\hline Variables & $\begin{array}{c}\text { Pre-IFRS(00-04) } \\
\text { (p-value })\end{array}$ & $\begin{array}{c}\text { Post-IFRS(05-09) } \\
\text { (p-value })\end{array}$ & $\begin{array}{c}\text { Expected } \\
\text { sign }\end{array}$ \\
\hline Constant & $\begin{array}{c}0.212 * * * \\
(0.000)\end{array}$ & $\begin{array}{c}0.044 * * * \\
(0.000)\end{array}$ & \\
\hline $\mathrm{OCF}$ & $\begin{array}{c}-0.061 * * * \\
(0.000)\end{array}$ & $\begin{array}{c}-0.035^{* * *} \\
(0.000)\end{array}$ & - \\
\hline LEV & $\begin{array}{r}0.171^{* *} \\
(0.035)\end{array}$ & $\begin{array}{c}0.135 \\
(0.224)\end{array}$ & + \\
\hline ROE & $\begin{array}{c}-0.025^{* * *} \\
(0.000)\end{array}$ & $\begin{array}{c}-0.015^{* * *} \\
(0.000)\end{array}$ & - \\
\hline ROA & $\begin{array}{c}-0.045^{* * *} \\
(0.000)\end{array}$ & $\begin{array}{c}-0.025^{* * *} \\
(0.000)\end{array}$ & - \\
\hline SIZE & $\begin{array}{c}-0.036^{* *} \\
(0.025)\end{array}$ & $\begin{array}{l}-0.060 \\
(0.314)\end{array}$ & $+/-$ \\
\hline AUGC & $\begin{array}{c}0.072 * * * \\
(0.007)\end{array}$ & $\begin{array}{r}0.059 * * \\
(0.045)\end{array}$ & + \\
\hline GROWTH & $\begin{array}{l}0.064^{* *} \\
(0.036)\end{array}$ & $\begin{array}{l}0.033 * \\
(0.089)\end{array}$ & + \\
\hline Adjusted R-square & 0.17 & 0.25 & \\
\hline F-stat & $9.580^{* *}$ & $12.874 * *$ & \\
\hline $\mathrm{N}$ & 435 & 435 & \\
\hline
\end{tabular}

Note. ${ }^{* * *}$ denotes significant level at $1 \%$; ** denotes significant level at $5 \%$; ${ }^{*}$ denotes significant level at $10 \%$. We report p-values in parentheses below the coefficients.

$$
\mathrm{PAD}_{\mathrm{it}}=\beta_{0}+\beta_{1} \mathrm{OCF}_{\text {it }}+\beta_{2} \mathrm{LEV}_{\mathrm{it}}+\beta_{3} \mathrm{ROE}_{\mathrm{it}}+\beta_{4} \mathrm{ROA}_{\mathrm{it}}+\beta_{5} \mathrm{SIZE}_{\mathrm{it}}+\beta_{6} \mathrm{AUGC}_{\mathrm{it}}+\beta_{7} \mathrm{GROWTH}_{\mathrm{it}}+\varepsilon_{\mathrm{it}}
$$

The dependent variable is the positive value of discretionary accruals. OCF is operating cash flow to lagged total assets, LEV is the leverage ratio estimated as total debt to total assets, ROE is return on equity estimated as net income to owners' equity, ROA is return on Assets estimated as net income to total assets, SIZE is the natural logarithm of market capitalization, AUGC is a binary variable that takes 1 when the firm has carried out a capital increase of more than $10 \%$ of the total shares outstanding during the year, 0 otherwise, GROWTH is the annual percentage change in sales. The model has been estimated including year fixed effects. 
We conclude through this comparative study between pre-IFRS period (2000-2004) and post-IFRS period (2005-2009) that the application of international accounting standards limits the earnings smoothing and management of discretionary accruals as well in magnitude as in positive sign.

To confirm our results, we will test the impact of IFRS on earnings management through discretionary accruals over the whole study period (2000-2009).

\section{Robustess Tests}

In order to further validate our results, we employ two additional regression models - run on the whole sample (pre- and post-IFRS) introducing the variable of interest IFRS.

IFRS is a dichotomous variable that represents the accounting system used, it takes 1 if IFRS are applied and 0 otherwise.

The models (8-9) are defined as follows:

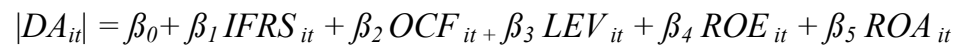

$$
\begin{aligned}
& +\beta_{6} \operatorname{SIZE}_{i t}+\beta_{7} A U G C_{I t}+\beta_{8} \text { GROWTH }_{i t}+\varepsilon_{i t} \\
& P A D_{i t}=\beta_{0}+\beta_{1} \text { IFRS }_{i t}+\beta_{2} O C F_{i t}+\beta_{3} L E V_{i t}+\beta_{4} R O E_{i t}+\beta_{5} R O A_{i t} \\
& +\beta_{6} S_{I Z E_{i t}}+\beta_{7} A U G C_{I t}+\beta_{8} \text { GROWTH }_{i t}+\varepsilon_{i t}
\end{aligned}
$$

Where $|\mathrm{DA}|$ is the absolute value of performance-matched discretionary accruals from the cross-sectional Jones (1991) model as being modified by Kothari et al. (2005), PAD is the positive value of performance-matched discretionary accruals, IFRS is a dichotomous variable that represents the accounting system used, it takes 1 if IFRS are applied, 0 otherwise, OCF is operating cash flow to lagged total assets, LEV is the leverage ratio estimated as total debt to owners' equity, ROE is return on equity estimated as net income to owners' equity, ROA is return on Assets estimated as net income to total assets, SIZE is the natural logarithm of market capitalization, AUGC is a binary variable that takes 1 when the firm has carried out a capital increase of more than $10 \%$ of the total shares outstanding during the year, 0 otherwise, GROWTH is the annual percentage change in sales.

By this study, we expect $\beta 1$ to be negative and statistically significant in both regressions

Table 9 below shows the results related to the estimation of models (8) and (9).

From Table 9, we can conclude that the models tested is generally significant, $\mathrm{R}^{2}$ has a value of $35 \%$ in the first column, where $|\mathrm{DA}|$ is used as a dependent variable , and $27 \%$ in the second column, where PDA is used as a dependent variable, which are in line with prior studies. (Iatridis, 2010-2012). We reject the null hypothesis stating that all coefficients are zero. The $\mathrm{X}^{2}$ test shows a probability less than $5 \%$, allowing us to retain the fixed-effects estimator for both models.

Table 9 shows that the coefficient of independent variable IFRS is negative and significant at the level of $1 \%$ (in both columns). This result shows that the application of IFRS reduces significantly discretionary accruals management as well in magnitude as in positive sign. This result confirms those obtained in comparative analysis and is consistent with previous studies (Daske \& Gebhardt, 2006).

Table 9. Regression results on earnings management with $|\mathrm{DA}|$ and PDA as dependent variable and IFRS as independent variable

\begin{tabular}{lccc}
\hline & $\begin{array}{c}\text { Model (8) } \\
|\mathbf{D A}|\end{array}$ & $\begin{array}{c}\text { Model }(9) \\
\text { PDA }\end{array}$ & \\
\hline Variables & Coefficient & Coefficient & Expected sign \\
& $(\boldsymbol{p}$-value $)$ & $(\boldsymbol{p}$-value $)$ & \\
Constant & $0.087^{* * *}$ & $0.098^{* * *}$ & \\
& $(0.000)$ & $(0.000)$ & - \\
IFRS & $-0.049^{* * *}$ & $-0.0052^{* * *}$ & - \\
& $(0.000)$ & $(0.000)$ & - \\
OCF & $-0.021^{* * *}$ & $-0.015^{* * *}$ & + \\
& $(0.000)$ & $(0.000)$ & \\
LEV & 0.031 & 0.012 & \\
& $(0.289)$ & $(0.203)$ & \\
\hline
\end{tabular}




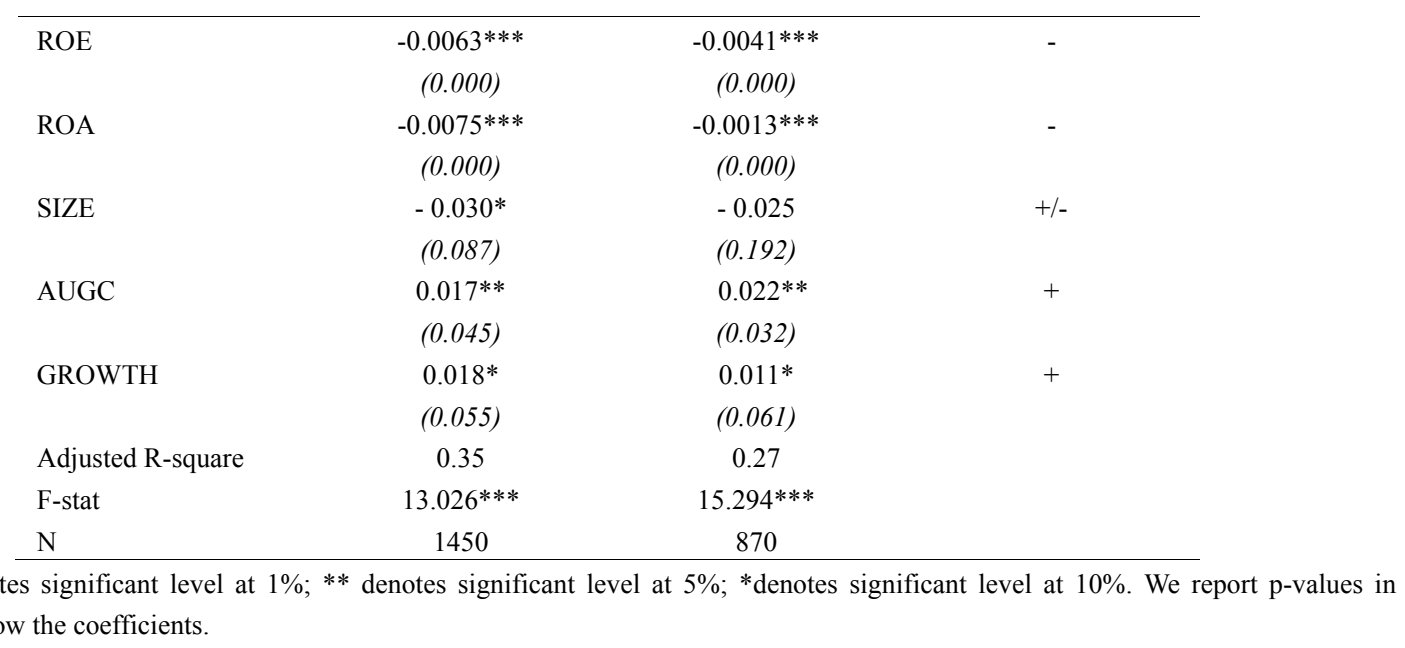

\section{Empirical Results Covering Economic Crisis Period}

To test the effect of IFRS on earnings management of French companies during the recent world economic crisis (2008-2009), after IFRS introduction, we have reduced the initial study period to five years, from 2005 (year of mandatory adoption of IFRS) to 2009, the number of observations is 725 .

We use the absolute value of discretionary accruals as a proxy for earning management. The argument for using absolute value is that we are interested in the existence of discretionary accruals and not in their direction and we introduce "Financial crisis FC" as variable of interest.

Financial crisis "FC" is a dichotomous variable that takes 1 if we are in the crisis period, 0 before

The model (10) is defined as follows:

$$
\begin{aligned}
\left|D A_{i t}\right|=\beta_{0} & +\beta_{1} F C_{i t}+\beta_{2} O C F_{i t}+\beta_{3} L E V_{i t}+\beta_{4} R O E_{i t}+\beta_{5} R O A_{i t} \\
& +\beta_{6} S I Z E_{i t}+\beta_{7} A U G C_{I t}+\beta_{8} G R O W T H_{i t}+\varepsilon_{i t}
\end{aligned}
$$

Where $|\mathrm{DA}|$ is the absolute value of performance-matched discretionary accruals from the cross-sectional Jones (1991) model as being modified by Kothari et al. (2005), FC is a dichotomous variable that takes 1 if we are in the crisis period, 0 before , OCF is operating cash flow to lagged total assets, LEV is the leverage ratio estimated as total debt to owners' equity, ROE is return on equity estimated as net income to owners' equity, ROA is return on Assets estimated as net income to total assets, SIZE is the natural logarithm of market capitalization, AUGC is a binary variable that takes 1 when the firm has carried out a capital increase of more than $10 \%$ of the total shares outstanding during the year, 0 otherwise, GROWTH is the annual percentage change in sales.

By this study, we expect $\beta 1$ to be negative and statistically significant.

Table 10 below shows the result related to the estimation of model (10).

From Table 10 , we can conclude that the models tested is generally significant, $\mathrm{R}^{2}$ has a value of $30 \%$ which are in line with prior studies. We reject the null hypothesis stating that all coefficients are zero. The $\mathrm{X}^{2}$ test shows a probability less than $5 \%$, allowing us to retain the fixed-effects estimator for model.

Table 10 shows that the coefficient of independent variable CF is negative and significant at the level of $1 \%$. This result shows that the financial crisis is not a motivation for earnings management when IFRS are applied by french companies. This result confirms those obtained previously and is consistent with previous studies (Gorgan, Gorgan, Dumitru, \& Pitulice, 2012). 
Table 10. Regression results on earnings management with $|\mathrm{DA}|$ as dependent variable and $\mathrm{CF}$ as independent variable after IFRS introduction

\begin{tabular}{lcc}
\hline & $\begin{array}{c}\text { Model }(10) \\
|\mathbf{D A}|\end{array}$ & \\
\hline Variables & $\begin{array}{c}\text { Coefficient } \\
(\boldsymbol{p} \text {-value })\end{array}$ & Expected sign \\
& $0.065^{* * *}$ & \\
Constant & $(0.000)$ & \\
& $-0.032^{* * *}$ & - \\
CF & $(0.000)$ & - \\
& $-0.015^{* * *}$ & \\
OCF & $(0.000)$ & + \\
& $0.045^{*}$ & - \\
LEV & $(0.089)$ & - \\
& $-0.0041^{* * *}$ & \\
ROE & $(0.000)$ & + \\
& $-0.0052^{* * *}$ & \\
ROA & $(0.000)$ & + \\
& $-0.027^{* * *}$ & \\
SIZE & $(0.000)$ & + \\
AUGC & $0.039^{* *}$ & \\
& $(0.045)$ & \\
GROWTH & $0.024^{* *}$ & \\
Adjusted R-square & $(0.029)$ & \\
F-stat & 0.30 & \\
$\mathrm{~N}$ & $11.015^{* * *}$ & \\
\hline
\end{tabular}

Note. $* * *$ denotes significant level at $1 \%$;* denotes significant level at $5 \%$; *denotes significant level at $10 \%$. We report p-values in parentheses below the coefficients.

\section{Conclusion and Future Research Directions}

This paper examines the effect of the adoption of the international accounting standards on the earning management of the French companies. We predict and find that the French companies exhibits significantly less earning management (lower magnitude of discretionary accruals and lower practices of income smoothing) in post-IFRS, even during the recent economic crisis.

Several researches examined the impact of the application of the IFRS, as high quality standards, on the earning management. Researchers showed that the standard IFRS, due to their principles, reduces the opportunist practices of the earning management. (Barth et al., 2008; Iatridis, 2010; Dimitropoulos et al., 2013; Doukakis, 2010). On the other hand, other researchers showed that the flexibility inherent in IFRS might provide greater opportunities for firms to manage earnings (Lin et al., 2012).

Previous literature has concentrated mainly on the voluntary adoption effect of IFRS. There is little research examining the mandatory adoption impact of IFRS on earning management in French companies.

Our contribution, through this study is to shed further light on the competing views regarding the efficacy and the self-sufficiency of IFRS to reduce earning management, even during the recent economic crisis, in France which is a code-law country, with low investor protection rights and a high level of earnings management and whose accounting standards were oriented stakeholder and accounting framework was characterized by historical-accounting principles.

Similarly, studies that have examined the impact of adopting IFRS on earnings management have generally focused on short-term periods, one to four years. We tried to extend the analysis to larger periods, five years pre-IFRS and five years post-IFRS to examine whether the impact of IFRS on earnings management (reduction or increasing) persists over time.

Our results should be of interest to all parties seeking to evaluate the benefits of mandatory adoption of IFRS as investors, managers, analysts, academics and the countries which have not made the decision yet to adopt the 
international accounting standards.

In future researches, we are going to examine the effect of the adoption of the IFRS on the earning' relevance and on the corporate governance system.

\section{References}

Ahmed, A. S., Neel, M., \& Wang, D. (2013). Does mandatory adoption of IFRS improve accounting quality? Preliminary evidence. Contemporary Accounting Research, 30(4), 1344-1372. http://dx.doi.org/10.1111/j.1911-3846.2012.01193.x

Barth, M. E., \& Konchitchki, Y. L. (2013). Cost of capital and earnings transparency. Journal of Accounting and Economics, 55(2-3), 206-224. http://dx.doi.org/10.1016/j.jacceco.2013.01.004

Barth, M. E., Landsman, W. R., \& Lang, M. H. (2008). International accounting standards and accounting quality. Journal of Accounting Research, 43, 467-498. http://dx.doi.org/10.1111/j.1475-679X.2008.00287.x

Bozec, Y. (2008). Ownership Concentration, Separation of Voting Rights from Cash Flow Rights, and Earnings Management: An Empirical Study in Canada. Canadian Journal of Administrative Science, 25(1), 1-15. http://dx.doi.org/10.1002/cjas.52

Brown, S., Lo, K., \& Lys, T. (1999). Use of $\mathrm{R}^{2}$ in accounting research: measuring changes in value relevance over the last four decades. Journal of Accounting and Economics, 28, 83-115. http://dx.doi.org/10.1016/S0165-4101(99)00023-3

Cai, L., Rahman, A., \& Courtenay, S. (2014). The Effect of IFRS Adoption Conditional Upon the level of Pre-adoption Divergence. The International Journal of Accounting. http://dx.doi.org/10.1016/j.intacc.2014.04.004

Cairns, D., Massoudi, D., Taplin, R., \& Tarca, A. (2011). IFRS fair value measurement and accounting policy. choice in the United Kingdom and Australia. The British Accounting Review, 43, 1-21. http://dx.doi.org/10.1016/j.bar.2010.10.003

Casta, J. F. (2000). Incertitude et comptabilité'. Encyclopédie de la comptabilité, du contrôle de gestion et de l'audit, Economica, 809-818.

Chen, H., Tang, Q., Jiang, Y., \& Lin, Z. (2010). The role of international financial reporting standards in accounting quality: Evidence from the European Union. Journal of International Financial Management and Accounting, 21, 220-278. http://dx.doi.org/10.1111/j.1467-646X.2010.01041.x

Christensen, H. B., Hail, L., \& Leuz, C. (2013). Mandatory IFRS reporting and changes in enforcement. Journal of Accounting and Economics, 56 (2-3, 1), 147-177. http://dx.doi.org/10.1016/j.jacceco.2013.10.007

Cormier, D., \& Martinez, I. (2006). The association between management earnings forecasts, earnings management, and stock market valuation: Evidence from French IPOs. The International Journal of Accounting, 41, 209-236. http://dx.doi.org/10.1016/j.intacc.2006.07.004

Daske, H., \& Gebhardt, G. (2006). International financial reporting standards and experts' perceptions of disclosure quality. Abacus, 42(3/4), 461-498. http://dx.doi.org/10.1111/j.1467-6281.2006.00211.x

Dechow, M., Sloan, R., \& Sweeney, A. (1995). Detecting earning management. The Accounting Review, 70(2), $193-225$.

DeFond, M. L. (2010). Earnings quality research: Advances, challenges and future research. Journal of Accounting and Economics, 50(2-3), 402-409. http://dx.doi.org/10.1016/j.jacceco.2010.10.004

Dimitropoulos, P. E., Asteriou, D., Kousenidis, D., \& Leventis, S. (2013). The impact of IFRS on accounting quality: Evidence from Greece. Advances in Accounting, 29(1), 108-123. http://dx.doi.org/10.1016/j.adiac.2013.03.004

Doukakis, L. C. (2010). The persistence of earnings and earnings components after the adoption of IFRS. Managerial Finance, 36, 969-980. http://dx.doi.org/10.1108/03074351011081286

Fu, R., Kraft, Ar., \& Zhang, H. (2012). Financial reporting frequency, information asymmetry, and the cost of equity. Journal of Accounting and Economics, 54(2-3), 132-149. http://dx.doi.org/10.1016/j.jacceco.2012.07.003

Ghosh, A., \& Olsen, L. (2008). Environmental uncertainty and managers' use of discretionary accruals. Accounting, Organizations and Society, 34(2), 188-205. http://dx.doi.org/10.1016/j.aos.2008.07.001 
Gorgan, C., Gorgan, V., Dumitru, V. F., \& Pitulice, I. C. (2012). The evolution of the accounting practices during the recent economic crisis: Empirical survey regarding the earnings management. The Amfiteatru Economics Journal, 14(32), 550-562.

Houque, M. N., Zijl, V. T., Dunstan, K., \& Karim, W. (2012). The effect of IFRS adoption and investor Horton, protection on earnings quality around the world. International Journal of Accounting, 47(3), 333-355. http://dx.doi.org/10.1016/j.intacc.2012.07.003

Iatridis, G. (2010). International Financial Reporting Standards and the quality of financial statement. information. International Review of Financial Analysis, 19, 193-204. http://dx.doi.org/10.1016/j.irfa.2010.02.004

Iatridis, G. (2011). Accounting disclosures, accounting quality and conditional and unconditional conservatism. International Review of Financial Analysis, 20, 88-102. http://dx.doi.org/10.1016/j.irfa.2011.02.013

Iatridis, G. (2012). Hedging and earnings management in the light of IFRS implementation: Evidence from the UK stock market. The British Accounting Review, 44, 21-35. http://dx.doi.org/10.1016/j.bar.2011.12.002

Iatridis, G. E. (2013). Environmental disclosure quality: Evidence on environmental performance, corporate governance and value relevance. Emerging Markets Review, 14, 55-75. http://dx.doi.org/10.1016/j.ememar.2012.11.003

Iatridis, G., \& Rouvolis, S. (2010). The post-adoption effects of the implementation of international financial reporting standards in Greece. Journal of International Accounting, Auditing and Taxation, 19, 55-65. http://dx.doi.org/10.1016/j.intaccaudtax.2009.12.004

Jeanjean, T., \& Stolowy, H. (2008). Do accounting standards matter? An exploratory analysis of earnings management before and after IFRS adoption. Journal of Accounting Public Policy, 27, 480-490. http://dx.doi.org/10.1016/j.jaccpubpol.2008.09.008

Jones, J. (1991). Earnings management during import relief investigations. Journal of Accounting Research, 29 , 193-228. http://dx.doi.org/10.2307/2491047

Klein, A. (2002). Audit committee, board of director characteristics and earnings management. Journal of Accounting and Economics, 33, 375-400. http://dx.doi.org/10.1016/S0165-4101(02)00059-9

Kothari, S. P., Leone, A. J., \& Wasley, C. E. (2005). Performance matched discretionary accrual measures. Journal of Accounting and Economics, 39, 163-197. http://dx.doi.org/10.1016/j.jacceco.2004.11.002

Landsman, W. R., Maydew, E. L., \& Thornock, J. R. (2012). The information content of annual earnings announcements and mandatory adoption of IFRS. Journal of Accounting and Economics, 53, 34-54. http://dx.doi.org/10.1016/j.jacceco.2011.04.002

Lang, M., Raedy, J. S., \& Wilson, W. (2006). Earnings management and cross listing: Are reconciled earnings comparable to US earnings? Journal of Accounting and Economics, 42(1-2), 255-283. http://dx.doi.org/10.1016/j.jacceco.2006.04.005

Leuz, C., Nanda, D., \& Wysocki, P. D. (2003). Earnings management and investor protection: An international $\begin{array}{lllll}\text { comparison. Journal of Financial } & \text { Economics, } & 69, & \text { 505-527. }\end{array}$ http://dx.doi.org/10.1016/S0304-405X(03)00121-1

Lin, S., Riccardi, W., \& Wang, C. (2012). Does accounting quality change following a switch from U.S.GAAP to IFRS? Evidence from Germany. Journal of Accounting Public Policy, 31, 641-657. http://dx.doi.org/10.1016/j.jaccpubpol.2012.10.006

Lobo, G. L., \& Zhou, J. (2001). Disclosure quality and earning management. Asia-Pacific Journal of Accounting \& Economics, 8(1), 1-20. http://dx.doi.org/10.1080/16081625.2001.10510584

Magnan, M. (2009). Fair value accounting and the financial crisis: messenger or contributor? Accounting Perspectives, 8(3), 189-213.

Marra, A., Mazzola, P., \& Prencipe, A. (2011). Board Monitoring and Earnings Management Pre- and Post-IFRS. The International Journal of Accounting, 46, 205-230. http://dx.doi.org/10.1016/j.intacc.2011.04.007

Perry, S., \& Williams, T. (1994). Earnings management preceding management buyout offers. Journal of Accounting and Economics, 18, 157-179. http://dx.doi.org/10.1016/0165-4101(94)00362-9

Plantin, G., Sapra, H., \& Shin, H. S. (2008). Comptabilisation en juste valeur et stabilité financière, Banque de $\begin{array}{lllll}\text { France. } & \text { Revue la } & \text { Stabilité } & \text { Financière, } & 12 .\end{array}$ 
http://www.banque-france.fr/fileadmin/user_upload/banque_de_france/publications/Revue_de_la_stabilite financiere/2008/octobre-2008/revue-stabilite-financiere-de-octobre-2008-etude-9-Comptabilisation-en-jus te-valeur-et-stabilite-financiere.pdf

Serafeim, J. G., \& Serafeim, I. (2013). Does mandatory IFRS adoption improve the information environment? Contemporary Accounting Research, 30(1), 388-423. http://dx.doi.org/10.1111/j.1911-3846.2012.01159.x

Stock, J. M., \& Watson, M. W. (2003). Introduction to econometrics. Pearson Education, Inc. Les États-Unis.

Tendeloo, B., \& Vanstrelen, A. (2005). Earnings management under German GAAP versus IFRS. European Accounting Review, 14, 155-180. http://dx.doi.org/10.1080/0963818042000338988

Theo, S. H., Welch, I., \& Wong, T. J. (1998). Earning management and the underperformance of seasoned equity offering. Journal of Finance Economics, 63-99.

Thong, T. Y., Ding, D. K., \& Lim, C. Y. (2008). Firm diversification and Earning management: evidence from seasoned equity offerings. Review of Quantitative Finance and Accounting, 30, 69-92. http://dx.doi.org/10.1007/s11156-007-0043-x

Watts, R., \& Zimmerman, J. (1978). Towards a Positive Theory of the Determination of Accounting Standards. The Accounting Review, 53(1), 112-134.

Watts, R., \& Zimmerman, J. (1986). Positive accounting theory. Prentice-Hall, Contemporary Topics Series, Englewood Cliffs, New Jersey.

Wehrfritz, M., \& Haller, A. (2014). National influence on the application of IFRS: Interpretations and accounting estimates by German and British accountants. Advances in International Accounting. http://dx.doi.org/10.1016/j.adiac.2014.03.010

Xiong, Y. (2006). Earning management and its measurement; a theoretical perspective. Journal of American Academy of Business, 9(1), 214-219.

Zeghal, D., Chtourou, S., \& Fourati, M. Y. (2012). The effect of mandatory adoption of IFRS on earning quality: evidence from the European Union. Journal of International Accounting Research, 11(2), 1-25. http://dx.doi.org/10.2308/jiar-10221

Zéghal, D., Chtourou, S., \& Mnif, S. Y. (2011). An analysis of the effect of mandatory adoption of IAS/IFRS on earnings Management. Journal of International Accounting, Auditing and Taxation, 20, 61-72. http://dx.doi.org/10.1016/j.intaccaudtax.2011.06.001

\section{Notes}

Note 1. The fair value introduced is determined by IFRS IAS 16 "tangible assets" as follows:

- The current market price,

- The amount the company would have paid for the asset at the acquisition date on trades between willing parties acting in normal competitive conditions; generally, it should be taken into account the outcome of recent transactions for similar assets.

IAS 39 "Financial Instruments: Recognition and Measurement" defined as well the fair value of a financial instrument:

- The current market price,

- The fair value of an instrument that is identique in substance,

- The future cash-flow discounted,

- The value determined by the valuation models options.

Note 2. The volatility concept refers to propensity, that to a variable to fluctuate unpredictably in time. More the value of an asset is likely to charge more this assets will be considered volatile and the risk of this asset will be high

\section{Copyrights}

Copyright for this article is retained by the author(s), with first publication rights granted to the journal.

This is an open-access article distributed under the terms and conditions of the Creative Commons Attribution license (http://creativecommons.org/licenses/by/3.0/). 